Zeszyty Naukowe Szkoły Głównej Gospodarstwa Wiejskiego w Warszawie

Problemy Rolnictwa Światowego tom 18 (XXXIII), zeszyt 1, 2018: 299-308

DOI: 10.22630/PRS.2018.18.1.27

Miroslawa Tereszczuk $^{1}$, Robert Mroczek ${ }^{2}$

Instytut Ekonomiki Rolnictwa i Gospodarki Żywnościowej - Państwowy Instytut

Badawczy w Warszawie

\title{
Wydajność pracy i koncentracja produkcji w polskim przemyśle spożywczym na tle krajów UE-28
}

\section{Labor Productivity and Concentration of Food Production in the Polish Food Industry against the EU-28}

\begin{abstract}
Synopsis. Przystapienie Polski do Unii Europejskiej okazało się korzystne dla rozwoju polskiego przemysłu spożywczego. Dynamicznemu rozwojowi produkcji w tym sektorze po 2004 roku, towarzyszyła poprawa wydajności pracy, która jest jednym z głównych czynników decydujących o konkurencyjności przedsiębiorstwa na rynku. W latach 2004-2014 wydajność pracy mierzona wartością produkcji sprzedanej wzrosła w polskim przemyśle spożywczym (w cenach porównywalnych) z 141,2 do 225,3 tys. euro/zatrudnionego i była już tylko o ok. 10 pkt proc. niższa niż przeciętnie w UE-28. Co ważne, wzrost wydajności pracy nastąpił, choć w różnym stopniu we wszystkich branżach przemysłu spożywczego w Polsce. W analizowanym okresie zmniejszyła się liczba przedsiębiorstw przemysłu spożywczego w większości krajów UE-28 i nastąpił wzrost koncentracji produkcji. Zmiany takie nastąpiły u największych producentów żywności UE-28, do których zaliczana jest też Polska.
\end{abstract}

Słowa kluczowe: przemysł spożywczy, produkcja, zatrudnienie, parytet, wydajność pracy

\begin{abstract}
The aim of this study was to show changes in labor productivity and concentration of production in the Polish food industry against the background of European Union countries and the indication of the causes (factors) which caused these changes. Poland's accession to the European Union has proved beneficial for the development of the Polish food industry. The dynamic development of production in this sector after 2004 has been accompanied by improved labor productivity, which is one of the main determinants of a company's competitiveness in the market. The assessment of changes in labor productivity was made at current prices, as well as at comparable prices, taking into account the purchasing power of currencies of individual member states. The method of compound interest was used to determine the average annual changes. In the years 2004 2014, labor productivity measured by the value of sold production increased in the Polish food industry (in comparable prices) from 141.2 to 225.3 thousand Euro/employee and was only about 10 percentage points lower than the EU-28 average. Importantly, productivity growth has occurred, although to a varying extent, in all sectors of the food industry in Poland. In the analyzed period, the number of food processing enterprises decreased in most EU-28 countries and the concentration of food production increased. Such changes have occurred in the largest EU-28 food producers, to which Poland is also counted.
\end{abstract}

Key words: food industry, production, employment, parity, labor productivity, Poland, UE-28

JEL Classification: J21, L23, L66

\footnotetext{
${ }^{1}$ mgr, Zakład Ekonomiki Przemysłu Spożywczego IERiGŻ-PIB, ul. Świętokrzyska 20, 00-002 Warszawa, e-mail: M.Tereszczuk@ ierigz.waw.pl

${ }^{2}$ dr inż., Zakład Ekonomiki Przemysłu Spożywczego IERiGŻ-PIB, ul. Świętokrzyska 20, 00-002 Warszawa, e-mail: Robert.Mroczek@ierigz.waw.pl
} 


\section{Wstęp}

W latach 2004-2014 poprawa wydajności pracy w polskim przemyśle spożywczym była zjawiskiem powszechnym i dotyczyła wszystkich jego branż. Wzrost wydajności pracy $\mathrm{w}$ tym sektorze należał do jednego $\mathrm{z}$ najszybszych w UE-28 i wynikał przede wszystkim z szybko rosnącej produkcji sprzedanej przemysłu spożywczego przy relatywnie niewielkim spadku zatrudnienia. Motorem wzrostu produkcji tego działu przemysłu w Polsce, w ostatnich latach był szybko rosnący eksport żywności - głównie do krajów członkowskich Unii Europejskiej wzrost cen zbytu na poziomie przetwórcy, oraz popyt wewnętrzny, zwłaszcza w pierwszych latach naszego członkostwa w UE (Drożdż, Tereszczuk, Mroczek, 2016). Innym ważnym czynnikiem wzrostu wydajności pracy w polskim przemyśle spożywczym były rosnące nakłady inwestycyjne, które przeznaczano m.in. na unowocześnianie majątku produkcyjnego przedsiębiorstw.

\section{Cel pracy i materiały}

Celem niniejszego opracowania było pokazanie zmian wydajności pracy i koncentracji produkcji w polskim przemyśle spożywczym na tle krajów Unii Europejskiej oraz wskazanie przyczyn (czynników), które te zmiany spowodowały. Oceny zmian wydajności pracy dokonano $\mathrm{w}$ cenach bieżących, jak też $\mathrm{w}$ cenach porównywalnych, uwzględniając siłę nabywczą walut poszczególnych krajów członkowskich. Do określenia średnich rocznych zmian wykorzystano metodę procentu składanego. Okresem badawczym objęto lata 2004-2014. W opracowaniu wykorzystano dane pochodzące z Eurostatu.

\section{Porównawcza ocena rozwoju przemysłu spożywczego w Polsce i innych krajach Unii Europejskiej w latach 2004-2014}

Znaczenie przemysłu spożywczego dla polskiej gospodarki jest zdecydowanie większe, niż w krajach Unii Europejskiej, o czym świadczy m.in. relacja wartości produkcji przemysłu spożywczego do PKB. Wartość obrotów sektora spożywczego w Polsce w 2014 roku odpowiadała $12,7 \%$ wartości wytworzonego PKB i była najwyższa wśród krajów UE28. W następnej kolejności były: Litwa, Belgia, Irlandia oraz Bułgaria, w których relacja ta wynosiła od 10,7 do 12,6\% przy średniej w UE-28 - 7,6\%, w tym w UE-15 - 7,3\%, a w UE-13 - 9,9\%. Poziom rozwoju przemysłu spożywczego, mierzony wartością obrotów na 1 mieszkańca w Polsce w 2014 roku wyniósł 2,4 tys. euro (w cenach porównywalnych) $\mathrm{i}$ był na podobnym poziomie, jak u największych producentów żywności $\mathrm{w}$ Unii Europejskiej, tj. Hiszpanii $(2,4)$, Niemiec $(2,2)$, czy Francji $(2,1)$ oraz średnio w UE-15 $(2,2)$ (obliczenia M. Tereszczuk na podstawie Eurostatu).

Polska jest szóstym producentem żywności pod względem wartości produkcji sprzedanej przemysłu spożywczego w UE (za Niemcami, Francją, Włochami, Hiszpanią i Wielką Brytanią) i co istotne w ciągu dekady umocniła swoją pozycję na tym rynku, gdyż jej udział w łącznej produkcji przemysłu spożywczego UE, zwiększył się o 1,6 pkt proc. z $6,9 \%$ w 2004 r. do $8,5 \%$ w 2014 r. (tab. 1). 
W latach 2004-2014 tempo rozwoju polskiego przemysłu spożywczego mierzone przyrostem wartości produkcji sprzedanej należało do jednego $\mathrm{z}$ najszybszych wśród krajów UE-28. W tym okresie wartość produkcji sprzedanej tego sektora (wyrażona $\mathrm{w}$ cenach bieżących, w euro) wzrosła w Polsce o 79,5\% (tj. 6,0\% rocznie), a w cenach porównywalnych prawie o $52 \%$, tj. o $4,2 \%$ rocznie. U największych producentów żywności w UE, tempo wzrostu było wolniejsze i wynosiło od $0,4 \%$ rocznie w Wielkiej Brytanii, 1,4-1,6\% we Francji i w Niemczech do 2,4\% we Włoszech i w Hiszpanii (tab. 1).

Tabela 1. Wartość, udział oraz tempo wzrostu produkcji sprzedanej przemysłu spożywczego w krajach UE-28 Table 1. Value, share and growth rate of output of sold food production in EU-28 countries

\begin{tabular}{|c|c|c|c|c|c|c|}
\hline \multirow{3}{*}{ Kraje UE } & \multicolumn{4}{|c|}{$\begin{array}{l}\text { Wartość produkcji } \\
\text { (w mld euro) }\end{array}$} & \multirow{3}{*}{$\begin{array}{c}\text { Udział } \\
\text { w produkcji } \\
\text { UE-28 w } 2014 \\
\text { roku } \\
\text { (w proc.) }\end{array}$} & \multirow{3}{*}{$\begin{array}{c}\text { Średnie tempo } \\
\text { wzrostu } \\
\text { produkcji }^{\text {b }} \\
\text { w latach } \\
\text { 2005-2014 } \\
\text { (w proc. rocznie) }\end{array}$} \\
\hline & \multicolumn{2}{|c|}{ w cenach bieżących } & \multicolumn{2}{|c|}{$\begin{array}{c}\text { w cenach } \\
\text { porównywalnych }\end{array}$} & & \\
\hline & 2004 & 2014 & 2004 & 2014 & & \\
\hline UE-15 & 775,7 & 926,7 & 728,3 & 879,2 & 82,3 & 1,9 \\
\hline UE-13 & 70,9 & 110,1 & 142,1 & 189,1 & 17,7 & 3,4 \\
\hline UE-28 & 846,6 & 1036,8 & 870,4 & 1068,3 & 100,0 & 2,1 \\
\hline Niemcy & 161,9 & 186,3 & 152,2 & 178,9 & 16,7 & 1,6 \\
\hline Francja & 138,0 & 154,6 & 122,8 & 140,7 & 13,2 & 1,4 \\
\hline Włochy & 106,5 & 128,9 & 101,2 & 128,9 & 12,1 & 2,4 \\
\hline Hiszpania & 79,9 & 100,6 & 88,7 & 112,7 & 10,5 & 2,4 \\
\hline W. Brytania & 111,0 & 122,8 & 99,9 & 104,4 & 9,8 & 0,4 \\
\hline Polska & 29,3 & 52,6 & 59,8 & 90,5 & 8,5 & 4,2 \\
\hline Holandia & 49,8 & 64,2 & 45,8 & 58,4 & 5,5 & 2,5 \\
\hline Belgia & 29,9 & 45,7 & 28,1 & 41,6 & 3,9 & 4,0 \\
\hline Irlandia & 21,6 & 23,8 & 17,9 & 21,4 & 2,0 & 1,8 \\
\hline Rumunia & 6,2 & 10,2 & 16,4 & 20,7 & 1,9 & 2,4 \\
\hline Czechy & 10,2 & 13,0 & 19,2 & 20,5 & 1,9 & 0,7 \\
\hline Austria & 12,0 & 20,2 & 11,5 & 18,6 & 1,7 & 4,9 \\
\hline Dania & 20,8 & 25,1 & 15,4 & 18,6 & 1,7 & 1,9 \\
\hline Węgry & 9,6 & 10,4 & 16,1 & 18,2 & 1,7 & 1,2 \\
\hline Portugalia & 11,2 & 14,0 & 13,1 & 18,1 & 1,7 & 3,3 \\
\hline Grecja & 10,0 & 12,6 & 12,1 & 15,4 & 1,4 & 2,4 \\
\hline Szwecja & 14,1 & 16,3 & 11,8 & 12,2 & 1,1 & 0,3 \\
\hline Bułgaria & 2,8 & 5,3 & 8,0 & 11,5 & 1,1 & 3,7 \\
\hline Finlandia & 8,2 & 10,7 & 7,1 & 8,6 & 0,8 & 1,9 \\
\hline Litwa & 2,0 & 3,9 & 4,1 & 6,5 & 0,6 & 4,7 \\
\hline Słowacja & 2,4 & 3,5 & 4,7 & 5,3 & 0,5 & 1,2 \\
\hline Lotwa & 1,2 & 1,8 & 2,5 & 2,7 & 0,3 & 0,8 \\
\hline Słowenia & 1,7 & 1,8 & 2,3 & 2,3 & 0,2 & 0,0 \\
\hline Estonia & 0,9 & 1,7 & 1,6 & 2,3 & 0,2 & 3,7 \\
\hline Cypr & 1,1 & 1,2 & 1,2 & 1,3 & 0,1 & 0,8 \\
\hline
\end{tabular}

${ }^{a}$ bez Malty i Chorwacji ze względu na brak danych, ${ }^{\text {b }}$ w cenach porównywalnych.

Źródło: opracowanie własne na podstawie Eurostat. 
Szybsze średnie tempo rozwoju przemysłu spożywczego w krajach UE-13 niż w krajach starej Unii nie dziwi, gdyż nowe kraje członkowskie dobrze wykorzystały posiadane przewagi komparatywne w postaci m.in. niższych cen surowców rolnych, niższej opłaty pracy, czego dobrym przykładem jest Polska. W ten sposób zmniejsza się dystans dzielący kraje UE-13 do UE-15.

\section{Zatrudnienie oraz wydajność pracy w przemyśle spożywczym}

Wydajność pracy określana jest najczęściej jako ilość dóbr i usług wytworzonych przez pracownika w jednostce czasu. Zależy ona od wielu czynników, w tym m.in. od:

- kwalifikacji i doświadczenia pracowników,

- technicznego uzbrojenia pracy (nowoczesności i wydajności maszyn i urządzeń),

- organizacji pracy,

- motywacyjnego systemu płac, a także nagród (Drożdż, Mroczek, Tereszczuk, 2016).

W 2014 roku w polskim przemyśle spożywczym zatrudnionych było prawie 402 tys. osób, co stanowiło blisko $10 \%$ ogółu zatrudnionych w przemyśle spożywczym Unii Europejskiej. Dało to nam czwarta pozycję wśród krajów UE-28. Wyższe zatrudnienie (w tys. osób) miały jedynie Niemcy (845), Francja (595) i Wielka Brytania (405), a nieznacznie niższe Włochy i Hiszpania (po ok. 340). W latach 2004-2014 nastapiło zmniejszenie liczby pracujących w przemyśle spożywczym w UE-28 o 5\%, przy czym w UE-15 o 4\%, a w UE-13 o prawie 8\%. W Polsce w tym czasie uległo ono zmniejszeniu o $5 \%$, tj. obniżało się w tempie $0,5 \%$ rocznie. Największy spadek zatrudnienia w sektorze spożywczym odnotowały: Łotwa (o 32\%), Słowenia (o 30\%) i Dania (o 22\%) oraz Czechy i Węgry (o 21\%). Wzrosło natomiast zatrudnienie w przemyśle spożywczym m.in.: Grecji (o 17\%), Austrii (o 4\%) oraz Niemiec (o 2,5\%) (tab. 2).

W 2014 roku na jednego zatrudnionego w przemyśle spożywczym w Polsce przypadało 225,3 tys. euro produkcji sprzedanej (w cenach porównywalnych) i była to wielkość wyższa o $1 / 3$ niż przeciętnie w UE-13, wyższa niż w Niemczech (211,8 tys. euro), ale dwukrotnie niższa niż w Irlandii (563,2 tys. euro), Holandii (468,7 tys. euro) oraz Belgii (462,2 tys. euro). W minionej dekadzie wydajność pracy w polskim przemyśle spożywczym wzrosła o blisko $60 \%$, podczas gdy średnio w UE-13 o $51 \%$, a w UE-15 o 26\%. Największy wzrost wydajności pracy w analizowanym okresie odnotowano na Litwie (+97,5\%) i w Estonii (+70\%) (tab. 2).

Tempo wzrostu wydajności pracy w polskim przemyśle spożywczym było wyższe niż w krajach UE-15. W latach 2004-2014 wzrastała ona średnio 4,8\% rocznie, podczas gdy w UE-15 - 2,3\% rocznie, a w krajach UE-13 - 4,2\% rocznie. Najwyższe tempo wzrostu wydajności pracy w ostatnim dziesięcioleciu odnotowano w krajach bałtyckich, tj. Litwie i Estonii i wynosiło 5,4-7,0\% rocznie (tab. 2).

Wydajność pracy w polskim przemyśle spożywczym mierzona wartością produkcji sprzedanej (w cenach porównywalnych) w 2004 roku stanowiła 73,5\% przeciętnej wydajności pracy w UE-28, a w 2014 roku wzrosła do 90,2\%, co oznacza, że w ciagu dekady dystans ten zmniejszył się o 16,7 pkt proc. Jest to zjawisko korzystne, gdyż poprawa wydajności pracy jest jednym z czynników konkurencyjności polskich przetwórców na rynkach zagranicznych. Co ważne, po przystąpieniu do Unii Europejskiej 
przyrost wydajności pracy w przemyśle spożywczym w Polsce był szybszy niż wzrost wynagrodzeń w tym sektorze i dotyczyło to większości branż przemysłu spożywczego (Judzińska, 2011; Mroczek, 2012). Relacja ta stworzyła dobre podstawy do dalszej poprawy efektywności produkcji w tym sektorze, a tym samym i jego konkurencyjności na rynkach międzynarodowych.

Tabela 2. Zatrudnienie oraz wydajność pracy w przemyśle spożywczym UE-28

Table 2. Employment and labor productivity in the EU-28 food industry

\begin{tabular}{|c|c|c|c|c|c|c|}
\hline \multirow{2}{*}{ Kraje } & \multicolumn{2}{|c|}{$\begin{array}{l}\text { Zatrudnienie } \\
\text { (w tys. osób) }\end{array}$} & \multirow{2}{*}{$\begin{array}{c}\text { Średnie tempo } \\
\text { zmian zatrudnienia } \\
\text { w latach } \\
\text { 2005-2014 } \\
\text { (w proc. rocznie) }\end{array}$} & \multicolumn{2}{|c|}{$\begin{array}{c}\text { Wydajność pracy } \\
\text { (w tys. euro/ } \\
\text { zatrudnionego) }\end{array}$} & \multirow{2}{*}{$\begin{array}{c}\text { Średnie } \\
\text { tempo zmian } \\
\text { wydajności pracy } \\
\text { w latach } \\
\text { 2005-2014 } \\
\text { (w proc. rocznie) }\end{array}$} \\
\hline & 2004 & 2014 & & 2004 & 2014 & \\
\hline UE-15 & 3319,0 & 3190,9 & $-0,4$ & 219,5 & 275,5 & 2,3 \\
\hline UE-13 & 1178,0 & 1087,0 & $-0,8$ & 115,3 & 174,0 & 4,2 \\
\hline UE-28 & 4497,0 & 4277,9 & $-0,5$ & 192,2 & 249,7 & 2,7 \\
\hline Austria & 74,6 & 77,5 & 0,4 & 154,2 & 240,0 & 4,5 \\
\hline Belgia & 91,6 & 90,0 & $-0,2$ & 306,8 & 462,2 & 4,2 \\
\hline Niemcy & 824,4 & 844,6 & 0,2 & 184,6 & 211,8 & 1,4 \\
\hline Dania & 78,8 & 61,2 & $-2,5$ & 195,4 & 303,9 & 4,5 \\
\hline Hiszpania & 363,5 & 335,2 & $-0,8$ & 244,0 & 336,2 & 3,3 \\
\hline Francja & 616,6 & 594,5 & $-0,4$ & 199,2 & 236,7 & 1,7 \\
\hline Finlandia & 37,4 & 38,7 & 0,3 & 189,8 & 222,2 & 1,6 \\
\hline Grecja & 67,0 & 79,1 & 1,6 & 178,5 & 194,7 & 0,9 \\
\hline Irlandia & 47,5 & 38,0 & $-2,2$ & 376,8 & 563,2 & 4,1 \\
\hline Włochy & 347,5 & 343,0 & $-0,1$ & 291,2 & 375,8 & 2,6 \\
\hline Holandia & 127,2 & 124,6 & $-0,2$ & 360,1 & 468,7 & 2,7 \\
\hline Portugalia & 100,8 & 99,6 & $-0,1$ & 130,0 & 181,7 & 3,4 \\
\hline Szwecja & 65,2 & 54,6 & $-1,8$ & 181,0 & 223,4 & 2,1 \\
\hline W. Brytania & 470,9 & 405,0 & $-1,5$ & 212,2 & 257,8 & 2,0 \\
\hline Luksemburg & 5,2 & 5,3 & 0,2 & 134,6 & 132,1 & $-0,2$ \\
\hline Polska & 423,5 & 401,7 & $-0,5$ & 141,2 & 225,3 & 4,8 \\
\hline Czechy & 132,9 & 104,4 & $-2,4$ & 144,5 & 196,4 & 3,1 \\
\hline Węgry & 128,3 & 101,3 & $-2,3$ & 125,5 & 179,7 & 3,7 \\
\hline Słowacja & 42,8 & 35,9 & $-1,7$ & 109,8 & 147,6 & 3,0 \\
\hline Słowenia & 20,9 & 14,7 & $-3,5$ & 110,1 & 156,5 & 3,6 \\
\hline Litwa & 53,3 & 42,8 & $-2,2$ & 76,9 & 151,9 & 7,0 \\
\hline Łotwa & 35,8 & 24,2 & $-3,8$ & 69,8 & 111,6 & 4,8 \\
\hline Estonia & 17,7 & 15,0 & $-1,6$ & 90,4 & 153,3 & 5,4 \\
\hline Cypr & 13,6 & 11,0 & $-2,1$ & 88,2 & 118,2 & 3,0 \\
\hline Rumunia & 203,6 & 180,9 & $-1,2$ & 80,6 & 114,4 & 3,6 \\
\hline Bułgaria & 105,6 & 93,9 & $-1,2$ & 75,6 & 122,5 & 4,9 \\
\hline
\end{tabular}

${ }^{\mathrm{a}}$ bez Malty i Chorwacji ze względu na brak danych, ${ }^{\mathrm{b}}$ w cenach porównywalnych.

Źródło: opracowanie własne na podstawie danych Eurostat. 
Tabela 3. Wydajność pracy ${ }^{\mathrm{a}} \mathrm{w}$ głównych działach przemysłu spożywczego największych producentów żywności w UE w 2014 roku (w tys. euro/zatrudnionego)

Table 3. Labor productivity in the major food industries of the largest food producers in the EU in 2014 (in thousands of euro/employed)

\begin{tabular}{|c|c|c|c|c|c|c|c|}
\hline Wyszczególnienie & Polska & Niemcy & Francja & W. Brytania & Włochy & Hiszpania & UE-28 \\
\hline $\begin{array}{l}\text { Przemysł spożywczy } \\
\text { ogółem }\end{array}$ & 225,3 & 211,8 & 236,7 & 257,8 & 375,8 & 336,2 & 249,7 \\
\hline \multicolumn{8}{|l|}{ w tym działy: } \\
\hline - tytoniowy & 787,6 & 1292,0 & 641,2 & bd & 233,3 & 502,2 & 1114,6 \\
\hline - nap. alkoholowych & 688,1 & 291,9 & 299,8 & 476,3 & 608,3 & 395,2 & 365,1 \\
\hline - olejarski & 384,6 & 935,1 & 1252,8 & 510,3 & 892,2 & 1047,9 & 829,8 \\
\hline - paszowy & 552,5 & 490,8 & 579,0 & 437,3 & 708,5 & 873,3 & 570,2 \\
\hline - zbożowo-młynarski & 269,0 & 345,8 & 378,6 & 454,3 & 920,0 & 595,7 & 380,4 \\
\hline - mleczarski & 339,3 & 692,9 & 482,1 & 371,0 & 500,0 & 497,4 & 459,7 \\
\hline - nap. bezalkoholowych & 304,4 & 254,9 & 475,9 & 417,8 & 471,8 & 516,0 & 351,8 \\
\hline - owocowo-warzywny & 153,6 & 258,7 & 266,0 & 185,9 & 350,0 & 291,4 & 228,4 \\
\hline - rybny & 207,2 & 244,1 & 232,0 & 226,4 & 410,0 & 268,7 & 221,2 \\
\hline - mięsny & 199,4 & 245,8 & 257,0 & 217,9 & 431,6 & 299,4 & 245,7 \\
\hline - piekarski & 76,7 & 52,3 & 85,3 & 99,3 & 87,6 & 94,8 & 70,0 \\
\hline
\end{tabular}

a bez Malty i Chorwacji ze względu na brak danych, ${ }^{\mathrm{b}}$ w cenach porównywalnych.

Źródło: opracowanie własne na podstawie danych Eurostat.

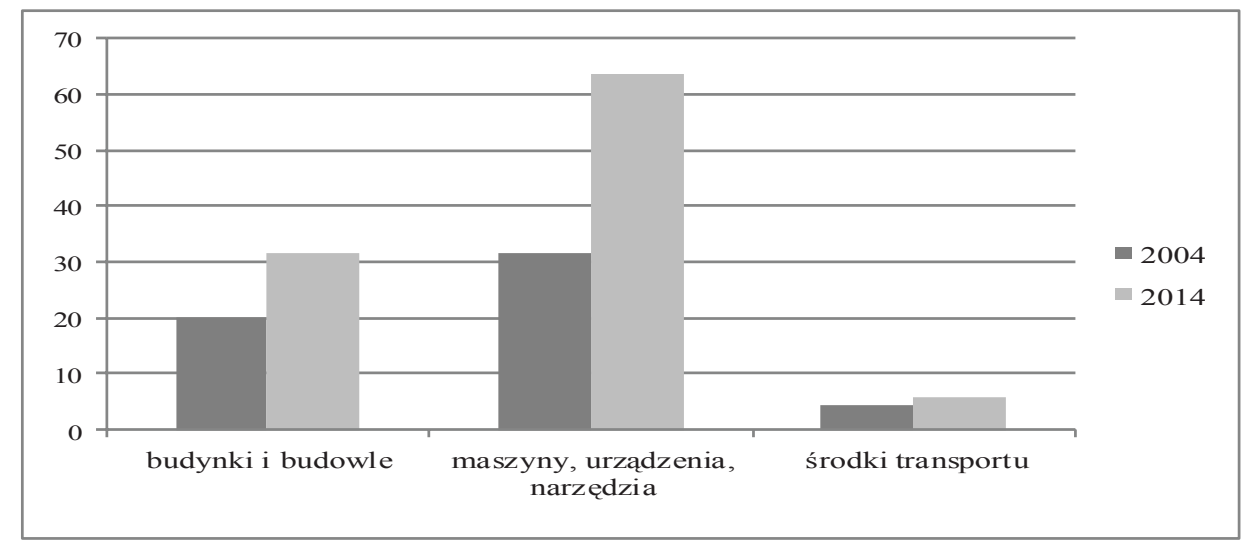

Rys. 1. Wartość brutto środków trwałych (wg cen ewidencyjnych) w przemyśle spożywczym w Polsce w latach 2004 i 2014 (w cenach bieżących, w mld zł)

Fig. 1. The gross value of fixed assets (according to fixed prices) in the food industry in Poland in 2004 and 2014 (in current prices, in billion PLN)

Źródło: opracowanie własne na podstawie Roczników Statystycznych GUS 2005 i 2015. 
Zróżnicowanie wydajności pracy w przemyśle spożywczym występuje nie tylko między krajami UE-28, ale także między poszczególnymi działami przetwórstwa w danym państwie. Wynika to z wielu czynników, w tym m.in.: z warunków naturalnych, specyfiki produkcji surowców rolnych i ich przetwórstwa, koncentracji produkcji, technicznego poziomu uzbrojenia pracy czy też rozwiązań prawnych (ustawodawstwa). W 2014 roku najwyższa wydajność pracy w przemyśle spożywczym w Polsce wystąiła branży: tytoniowej, napojów alkoholowych, paszowej (od 553 tys. euro do 788 tys. euro/zatrudnionego), a o połowę mniejsza w przemyśle olejarskim, mleczarskim i napojów bezalkoholowych. Cechą wspólną u wszystkich największych producentów żywności UE jest najniższa wydajność pracy w przemyśle piekarskim, co wynika z jego bardzo dużego rozdrobnienia.

Poprawa wydajności pracy w polskim przemyśle spożywczym w latach 2004-2014 nie dokonałaby się bez dużego ożywienia inwestycyjnego po przestapieniu do UE, w wyniku czego nastąiło unowocześnienie parku maszynowego (majątku czynnego) firm przetwórczych. W analizowanej dekadzie łączne nakłady inwestycyjne w całym przemyśle spożywczym (razem z produkcją wyrobów tytoniowych) wyniosły ok. 83 mld zł. W tym czasie wartość brutto maszyn, urządzeń, narzędzi w przedsiębiorstwach tego sektora wzrosła dwukrotnie z 31,7 do 63,6 mld zł, wartość budynków i budowli (majątek bierny) zwiększyła się o $56,7 \%$ (z 20,2 do 31,7 mld zł), zaś środków transportu o $26,6 \%$ (z 4,5 do 5,7 mld zł) (rys. 1). Taka struktura inwestycji ma swoje uzasadnienie ekonomiczne, gdyż nowe bardziej wydajne maszyny i urządzenia podnoszą efektywność produkcji. Ponadto okres amortyzacji majątku czynnego jest kilkakrotnie krótszy niż budynków i budowli (majątku biernego).

\section{Koncentracja produkcji w przemyśle spożywczym}

W Polsce w 2014 roku produkcją żywności zajmowało się ok. 13 tys. przedsiębiorstw. Stanowiło to $4,5 \%$ unijnych przedsiębiorstw spożywczych i dawało nam szóstą pozycję wśród krajów UE-28 (tab. 4). W latach 2004-2014 ich liczba w Polsce zmniejszyła się prawie o $28 \%$ a przeciętnie w UE-15 o ok. $9 \%$. W tym okresie liczba firm spożywczych w krajach UE-13 wzrosła średnio o 3,3\% a w takich krajach jak Słowenia i Słowacja aż dwuipółkrotnie-trzyipółkrotnie, ale tak duży wzrost wynikał ze stosunkowo małej liczny firm na początku badanego okresu (niespełna 1000 przedsiębiorstw). W grupie tych państw wzrost liczby przedsiębiorstw nastapił jeszcze: na Litwie, Łotwie, w Estonii i Czechach i wynosił od $20 \%$ do $44 \%$. Tak duża zmiana w liczbie funkcjonujących przedsiębiorstw w polskim przemyśle spożywczym wynikała z postępującego procesu koncentracji, co przyczyniło się do poprawy naszej pozycji konkurencyjnej na Wspólnym Rynku Europejskim (Drożdż, Mroczek, Tereszczuk, 2015).

Obroty przeciętnej firmy wskazują na zwiększenie siły ekonomicznej i konkurencyjności polskich przedsiębiorstw spożywczych na rynku europejskim. Wartość obrotów przedsiębiorstw przetwórstwa spożywczego w Polsce w 2014 roku wynosiła prawie 7,0 $\mathrm{mln}$ euro na firmę i była ponad dwukrotnie większa niż w 2004 roku. Przeciętny poziom obrotów firmy spożywczej w UE-15 w 2014 roku osiagnął wartość 3,8 mln euro. Oznacza to, że pozycja polskich firm spożywczych na tle UE przedstawia się relatywnie dobrze. Średnie obroty osiagane przez przedsiębiorstwa spożywcze w Polsce są wyższe od niemieckich firm spożywczych $(6,0 \mathrm{mln}$ euro) oraz znacznie wyższe niż w: Grecji, Włoszech, Portugalii, czy Francji. Natomiast są dużo niższe niż w: Irlandii (34,8 mln euro), Wielkiej Brytanii (13,1 $\mathrm{mln}$ euro) oraz Danii (11,3 mln euro) i Holandii (10,2 mln euro) (tab. 4). 
Tabela 4. Liczba przedsiębiorstw oraz średnia wartość obrotów firmy w przemyśle spożywczym UE-28,b

Table 4. Number of enterprises and the average value of turnover in the EU food industry

\begin{tabular}{|c|c|c|c|c|c|c|}
\hline \multirow[t]{2}{*}{ Kraje } & \multicolumn{2}{|c|}{$\begin{array}{l}\text { Liczba firm } \\
\text { (w tys.) }\end{array}$} & \multirow{2}{*}{$\begin{array}{c}\text { Zmiana } \\
2014 / 2004 \\
(2004=100)\end{array}$} & \multicolumn{2}{|c|}{$\begin{array}{l}\text { Obroty } 1 \text { firmy } \\
\text { (w mln euro) }\end{array}$} & \multirow{2}{*}{$\begin{array}{c}\text { Zmiana } \\
2014 / 2004 \\
2004=100\end{array}$} \\
\hline & 2004 & 2014 & & 2004 & 2014 & \\
\hline UE-15 & 256,89 & 233,20 & 90,8 & 2,84 & 3,77 & 132,7 \\
\hline UE-13 & 54,23 & 56,03 & 103,3 & 2,50 & 3,32 & 132,8 \\
\hline UE-28 & 311,12 & 289,23 & 93,0 & 2,78 & 3,68 & 132,4 \\
\hline Austria & 4,33 & 3,83 & 88,5 & 2,66 & 4,75 & 178,6 \\
\hline Belgia & 8,21 & 7,47 & 91,0 & 3,42 & 5,45 & 159,4 \\
\hline Niemcy & 32,61 & 29,61 & 90,8 & 4,67 & 6,04 & 129,3 \\
\hline Dania & 1,78 & 1,60 & 89,9 & 8,65 & 11,31 & 130,8 \\
\hline Hiszpania & 29,86 & 27,39 & 91,7 & 2,97 & 4,04 & 136,0 \\
\hline Francja & 68,15 & 58,70 & 86,1 & 1,80 & 2,34 & 130,0 \\
\hline Finlandia & 1,89 & 1,74 & 92,1 & 3,76 & 5,00 & 133,0 \\
\hline Grecja & 14,80 & 15,51 & 104,8 & 0,82 & 0,95 & 115,9 \\
\hline Irlandia & 0,60 & 0,62 & 103,3 & 29,83 & 34,84 & 116,8 \\
\hline Włochy & 70,08 & 57,50 & 82,0 & 1,44 & 2,22 & 154,2 \\
\hline Holandia & 4,56 & 5,70 & 125,0 & 10,04 & 10,23 & 101,9 \\
\hline Portugalia & 9,50 & 10,81 & 113,8 & 1,38 & 1,59 & 115,2 \\
\hline Szwecja & 3,26 & 3,96 & 121,5 & 3,62 & 3,08 & 85,1 \\
\hline W. Brytania & 7,07 & 8,61 & 121,8 & 14,13 & 13,12 & 92,9 \\
\hline Luksemburg & 0,19 & 0,15 & 78,9 & 3,68 & 4,67 & 126,9 \\
\hline Polska & 18,29 & 13,13 & 71,8 & 3,27 & 6,95 & 212,5 \\
\hline Czechy & 6,09 & 8,76 & 143,8 & 3,15 & 2,16 & 68,6 \\
\hline Węgry & 6,97 & 6,76 & 97,0 & 2,31 & 2,68 & 116,0 \\
\hline Słowacja & 0,81 & 2,85 & 351,9 & 5,80 & 1,79 & 30,9 \\
\hline Słowenia & 0,84 & 2,16 & 257,1 & 2,74 & 1,02 & 37,2 \\
\hline Litwa & 1,23 & 1,53 & 124,4 & 3,33 & 4,18 & 125,5 \\
\hline Łotwa & 0,79 & 0,97 & 122,8 & 3,16 & 2,78 & 88,0 \\
\hline Estonia & 0,44 & 0,53 & 120,5 & 3,64 & 4,34 & 119,2 \\
\hline Cypr & 1,03 & 0,90 & 87,4 & 1,17 & 1,56 & 133,3 \\
\hline Rumunia & 10,91 & 8,81 & 80,8 & 1,50 & 2,27 & 151,3 \\
\hline Bułgaria & 6,37 & 5,98 & 93,9 & 1,26 & 1,94 & 154,0 \\
\hline
\end{tabular}

${ }^{a}$ bez Malty i Chorwacji ze względu na brak danych, ${ }^{b}$ mierzone wartością produkcji sprzedanej $\mathrm{w}$ cenach porównywalnych.

Źródło: opracowanie własne na podstawie danych Eurostat.

Największa koncentracja produkcji w przemyśle spożywczym w Polsce wystapiła branży: tytoniowej, napojów alkoholowych, mleczarskiej, mniejsza w przemyśle paszowym i olejarskim. Jednocześnie $\mathrm{w}$ tych działach przetwórstwa (poza tytoniowym) koncentracja produkcji była w Polsce wyższa niż przeciętnie w UE-28 (tab. 5). Najmniejsza rozpiętość obrotów przypadająca na jedną firmę w poszczególnych branżach przemysłu spożywczego, wśród największych producentów produktów spożywczych w UE-28, występowała we Włoszech oraz Hiszpanii (od 0,24 mln euro do 23,33 mln euro) (tab. 5). Cechą wspólną przemysłów spożywczych tych krajów, były najniższe obroty firm piekarskich (od 0,24 mln euro we Włoszech do 3,41 mln euro w Wlk. Brytanii). Tak niskie obroty firm tej branży mogą wynikać z dużej ich liczby oraz struktury własności, gdyż często są to przedsiębiorstwa rodzinne. 
Tabela 5. Koncentracja produkcji w przemyśle spożywczym największych producentów żywności UE mierzona wartością produkcji sprzedanej $j^{\mathrm{a}}$ przeciętnej firmy spożywczej w 2014 roku (w mln euro)

Table 5. Concentration of production in the food industry of the largest EU food producers measured by the value of sold production by the average food company in 2014 (million euro)

\begin{tabular}{l|rrrrrrr}
\hline \multicolumn{1}{c|}{ Wyszczególnienie } & Polska & Niemcy & Francja & W. Brytania & Włochy & Hiszpania & UE-28 \\
\hline P. spożywczy ogółem & 6,95 & 6,04 & 2,34 & 13,12 & 2,22 & 4,04 & 3,68 \\
w tym działy: & & & & & & & \\
- tytoniowy & 110,24 & 644,76 & 155,71 & bd & 23,33 & 21,54 & 141,81 \\
- nap. alkoholowych & 41,82 & 8,83 & 6,14 & 12,12 & 4,49 & 2,57 & 5,10 \\
- olejarski & 15,40 & 31,30 & 15,90 & 12,30 & 1,90 & 8,30 & 5,80 \\
- paszowy & 16,20 & 14,50 & 24,80 & 16,20 & 9,00 & 13,60 & 13,60 \\
- zbożowo-młynarski & 4,50 & 6,92 & 8,58 & 30,44 & 6,50 & 8,01 & 5,80 \\
- mleczarski & 42,20 & 93,4 & 31,4 & 23,00 & 5,60 & 7,20 & 15,30 \\
- nap. bezalkoholowych & 11,84 & 14,94 & 18,20 & 17,49 & 17,40 & 22,55 & 10,35 \\
- owocowo-warzywny & 4,35 & 14,75 & 4,73 & 8,93 & 5,10 & 6,58 & 4,85 \\
- rybny & 12,31 & 7,46 & 8,87 & 9,94 & 5,10 & 9,02 & 7,18 \\
- mięsny & 9,32 & 4,36 & 3,70 & 17,00 & 6,60 & 7,03 & 5,73 \\
- piekarski & 1,16 & 1,30 & 0,41 & 3,21 & 0,24 & 0,53 & 0,58 \\
\hline
\end{tabular}

${ }^{\mathrm{a}} \mathrm{w}$ cenach porównywalnych.

Źródło: opracowanie własne na podstawie danych Eurostat.

Proces koncentracji i konsolidacji branży spożywczej postępuje w całej Unii Europejskiej. W Polsce przebiega on znacznie szybciej niż u większości innych członków UE. Zmniejsza się dystans dzielący nas od krajów o wysokiej koncentracji produkcji w tym sektorze.

\section{Konkluzje}

1. W latach 2004-2014 wydajność pracy w polskim przemyśle spożywczym zwiększyła się (w cenach porównywalnych) o blisko $60 \%$ (z 141,2 tys. euro do 225,3 tys. euro/zatrudnionego), a tempo wzrostu wydajności pracy w tym czasie wynosiło 4,8\% rocznie i było jednym z najszybszych wśród krajów UE-28.

2. Wydajność pracy $\mathrm{w}$ polskim przemyśle spożywczym mierzona wartością produkcji sprzedanej (w cenach porównywalnych) w 2004 roku stanowiła 73,5\% przeciętnej wydajności pracy w UE-28, a w 2014 roku wzrosła do 90,2\%, co oznacza, że w ciągu dekady dystans ten zmniejszył się o 16,7 pkt proc. Jest to zjawisko korzystne, gdyż poprawa wydajności pracy jest jednym $\mathrm{z}$ czynników konkurencyjności polskich przetwórców na rynkach zagranicznych.

3. W analizowanym okresie poprawa wydajności pracy w polskim przemyśle spożywczym wynikała z szybko rosnącej produkcji sprzedanej tego sektora przy relatywnie niewielkim spadku zatrudnienia. Motorem wzrostu produkcji sprzedanej stał się eksport, wzrost cen na poziomie przetwórcy oraz popyt wewnętrzny. Wpływ tych czynników był różny w poszczególnych latach, zwłaszcza jeżeli chodzi o ostanie dwa z nich. (Mroczek 2016). Innymi ważnymi czynnikami tego wzrostu były: wzrost poziomu technicznego uzbrojenia pracy (w wyniku rosnących nakładów inwestycyjnych, 
zwłaszcza w aktywny majątek produkcyjny, tj. maszyny, urządzenia i narzędzia) oraz postępująca koncentracja produkcji i przetwórstwa żywności.

4. Istotne jest to, że wzrost wydajności pracy w polskim przemyśle spożywczym w minionej dekadzie, był zjawiskiem powszechnym i dotyczył wszystkich branż tego sektora. Stwarza to dobre podstawy do utrzymania i dalszego budowania konkurencyjności na rynku UE, ale też na rynkach krajów trzecich, tym bardziej, że proste przewagi konkurencyjne w postaci tańszych cen surowców rolnych, niższych kosztów pracy powoli zanikają.

\section{Literatura}

Drożdż, J., Mroczek, R., Tereszczuk, M. (2015). Rozwój przemysłu spożywczego w Polsce i innych krajach Unii Europejskiej (The development of the food industry in Poland and other European Union countries). W: R. Mroczek (red.) Przemiany strukturalne przemysłu spożywczego w Polsce i UE na tle wybranych elementów otoczenia zewnętrznego, Program Wieloletni 2015-2019, Raport nr 12, IERiGŻ-PIB, Warszawa.

Drożdż, J., Tereszczuk, M., Mroczek, R. (2016). Społeczno-ekonomiczne uwarunkowania poprawy wydajności pracy w polskim przemyśle spożywczym na tle krajów Unii Europejskiej (Socio-economic conditions for improving labor productivity in the Polish food industry compared to the European Union countries). W: A. Kowalski, M. Wigier Konkurencyjność gospodarki w kontekście działań polityki społecznej perspektywa krajowa, Program Wieloletni 2015-2019, Raport nr 26, IERiGŻ-PIB, Warszawa.

Eurostat data. Pobrane z: http://ec.europa.eu/eurostat/data/database.

Judzińska, A. (2011). Zatrudnienie i wynagrodzenie w przemyśle spożywczym (Employment and wages in the food industry), W: R. Mroczek (red.) Procesy dostosowawcze polskiego przemysłu spożywczego do zmieniającego się otoczenia rynkowego (1), Program Wieloletni 2011-2014, Raport nr 4, IERiGŻ-PIB, Warszawa.

Mroczek, R. (2016). Przemysł spożywczy (Food industry). W: R. Mroczek (red.) Przetwórstwo produktów pochodzenia roślinnego w Polsce w latach 2010-2015, Program Wieloletni 2015-2019, Raport nr 39, IERiGŻ-PIB, Warszawa.

Mroczek, R. (2012). Zatrudnienie i wynagrodzenia w przemyśle spożywczym (Employment and wages in the food industry). W: R. Mroczek (red.) Procesy dostosowawcze polskiego przemysłu spożywczego do zmieniającego się otoczenia rynkowego (2), Program Wieloletni 2011-2014, Raport nr 35, IERiGŻ-PIB, Warszawa.

Roczniki Statystyczne GUS z lat 2005-2015 (Statistical Yearbooks of the Central Statistical Office from 2005-2015).

Do cytowania / For citation:

Tereszczuk M., Mroczek R. (2018). Wydajność pracy i koncentracja produkcji w polskim przemyśle spożywczym na tle krajów UE-28. Problemy Rolnictwa Światowego, 18(1), 299-308; DOI: 10.22630/PRS.2018.18.1.27

Tereszczuk M., Mroczek R. (2018). Labor Productivity and Concentration of Food Production in the Polish Food Industry Against the EU-28 (in Polish). Problems of World Agriculture, 18(1), 299-308; DOI: $10.22630 /$ PRS.2018.18.1.27 